\title{
FORESTRY OWNERSHIP AND FORESTRY PRACTICE
}

\author{
By I. KAGIS
}

\author{
Saskatchewan Forest Service, Regina, Saskatchewan
}

It is often said that a question asked in the right way contains one-half of the answer. If we speak about tenure of forest land in different countries, two questions could be asked. First, what amount or what percentage of the forest area of a country is held by different classes of owners-crown, companies, farmers, etc? The figures, giving an answer to this question would be of considerable interest to an economist, to a statistician or even to a sociologist. But a forester, when studying such figures, feels that they do not tell him the story he wants to know. He feels that he is compelled to ask a second question, namely, what influence do these figures have on the practice of good forestry, or in other words, is better forestry practised in countries where the forests are owned privately or in those countries where the main owners are communities, the state, etc.?

If the forester who asks the question approaches the problem without having his mind made up in advance, if he wants an answer given by facts and figures, he would feel himself in a very difficult position. The more conscientiously he trys to find a definite answer the less he is assured of the possibility of obtaining one which is absolutely "waterproof and fireproof". He might try to eliminate a multitude of causes by picking examples where all circumstances are equal except one. Then he would see how this one factor which is different in different countries influences the result. At the very beginning he would see that this method which normally would be the most promising one is not fully applicable in this case because there are not two countries where all factors which have an influence on the forestry practice, climate, history, general economy, communications, etc., are the same except the distribution of forest land amongst different classes of owners. Likewise there are not two countries where all the circumstances, including tenure are the same. Sometimes the distribution of forest land amongst owners is approximately the same but other circumstances are different. Supported by such evidence it is possible to state only that there are some definite tendencies.

My late professor of silvics used to quote a saying of the well known Professor Morozov, the originator of biological forest typology: "With closed eyes I could say if I am in a private forest or in a crown forest." There is no doubt that there were several places in old Czarist Russia which justified such a statement, but this is a typical statement which is true for the time and the place, but not for another place at another time.

In 1925 I had the unpleasant duty of dealing with two districts which had been "managed" by private owners. The result of their "management" was that valuable stands of Scots pine (Pinus silvestris) in the upper, and Norway spruce (Picea excelsa) in the lower story were converted into stands of pure spruce. All the pine and even the best spruce had been removed. There was left behind what we called a pseudo-spruce type, spruce on pine soil. Volume increment was reduced by about one-third and the 
value of the total increment reduced by about one-halt in comparison with the original stands.

In Germany I have worked in a district of crown forests which were managed on what I would call a superintensive basis (Wald-Feldbau) to improve the site quality. However, I have seen some places in this crown forest where trees, killed by Ips typographus and Ips cbalcograpbus were not taken out in time and where nobody cared what happened to the soil. In the same country I have inspected some private forests which were a joy to every forester's eye. In Austria I have seen very well managed state forests and some large private forests which were particularly well managed. There were similar examples in Czechoslovakia. Lastly, I would like to mention a case described by D. W. MacLean in Silvicultural Research Note 95 of the Dominion Forest Service. The author of this research note tells about a forest of a private company which originally consisted of white pine in the top story and more or less tolerant hardwoods underneath. This was an excellent starting combination. Then the pine was removed about 50 years ago and the best hardwood was taken out. Result -area of huge "apple trees". (This case reminds me very much of the pseudo-spruce stands). But everybody, no doubt, has seen areas in the provincial forests of this country which could be placed in the same category.

If anyone came to a definite conclusion on the basis of similar examples, he inevitably would be subject to severe criticism. These are nothing more than separate cases which often are the result, not only of a multitude of objective factors, such as economy, history, etc, but often are influenced by the attitude of a single person.

A more promising method is the comparison of increment yield in forests of the same country and the gathering of other data on forests, held by different categories of owners. But there are two circumstances to be taken into consideration in this method. Firstly, it is evident that the results obtained cannot be applied to all countries. Secondly, there are not many countries where such figures are available.

If, under such circumstances, a forester steps up and bluntly states that, for instance, private ownership is the panacea for all forestry practice and tries to prove this by means of not-to-well interpreted statistics on forest tenure in one or two countries, let him weigh his conclusions and search his soul.

Now let us examine some figures to see if some tendencies can be traced. The figures on forest tenure in Germany supplied by the Food and Agricultural Organization of the United Nations are as indicated in Table I.

From these figures we see that Germany is a country where the forests are predominantly publicly owned; in $1946,38.1+21.6=59.7$ or in round figures 60 per cent of all forests were publicly owned (State and community). In 1936 the corresponding figures were $20.5+33.4=53.9$ per cent or in round figures 54 per cent. In addition to that, all forests are under the control of forestry officers of the state. The average annual increment is 4.2 cubic meters per hectare, which is by no means a low one (equal approximately to 59.3 cubic feet per acre). In accordance with other figures (for 1949) given by the same 
FOREST OWNERSHIP-KAGIS

Table I.

AREA of Forests in Germany

\begin{tabular}{|l|c|c|c|c|}
\hline \multirow{2}{*}{ Forest Ownership } & \multicolumn{2}{|c|}{ In 1937} & \multicolumn{2}{|c|}{ In 1946 } \\
\cline { 2 - 5 } & 1000 ha. & $\%$ & 1000 ha. & $\%$ \\
\hline \hline State & 4.253 & 33.4 & 3.656 & 38.1 \\
Community & 2.614 & 20.5 & 2.070 & 21.6 \\
Private: & & & & \\
Over 10 ha. & 4.119 & 32.8 & 2.181 & 22.8 \\
Under 10 ha. & 1.689 & 13.3 & 1.678 & 17.5 \\
\hline & 12.675 & & 9.585 & \\
\hline
\end{tabular}

The corresponding annual growth rates in German forests are as below:

\section{Cubic Metres Per Hectare}

\begin{tabular}{|l|c|c|c|}
\hline Forest Ownership & Conifers & Broadleaved & All Species \\
\hline State forests & 4.6 & 3.6 & 4.3 \\
Community forests & 5.3 & 3.6 & 4.6 \\
Private forests & 4.1 & 2.9 & 3.8 \\
(Over 10 ha.; & & & \\
about 25 acres) & & & \\
\hline All Forests & 4.6 & 3.4 & 4.2 \\
\hline
\end{tabular}

source, this average increment is 3.31 cubic meters per hectare. The explanation for this discrepancy might be the fact that in the above table of annual increments, private forests under 10 ha. where the annual increment is much lower are not included. In a separate publication of the FAO "Forest Resources of the World," net increment is given as 3.6 cubic metres per hectare.

If we look at the annual increment in forests held by different classes of owners we see that there is a distinct tendency in favour of publicly owned forests. In these forests, state and community, the average annual increment is somewhere around 4.4 to 4.5 cubic metres per hectare. For the privately owned forests over $10 \mathrm{ha}$. the figure is 3.8. Figures on distribution of age classes to show which forests are more overcut would be valuable but we know that in Germany all forests had to be overcut by orders of government in connection with the war. 


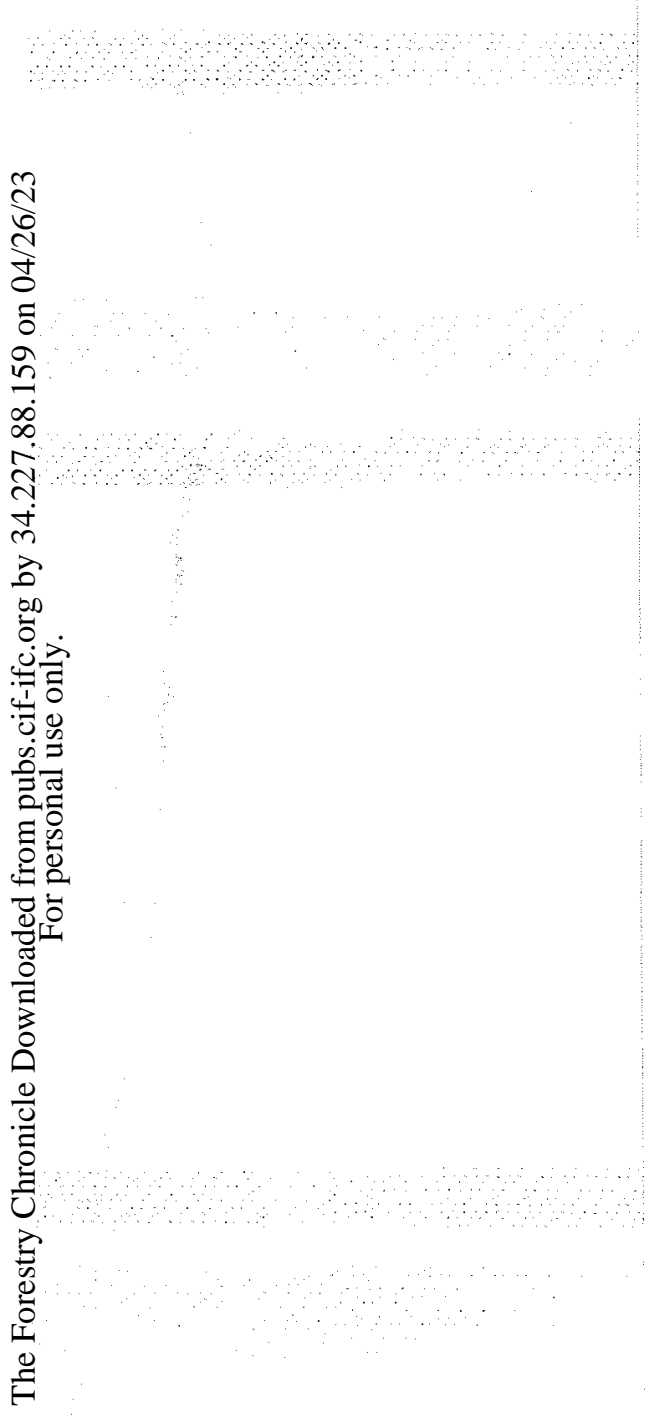
In my former country, Latvia, the latest figures on forest tenure are as follows:

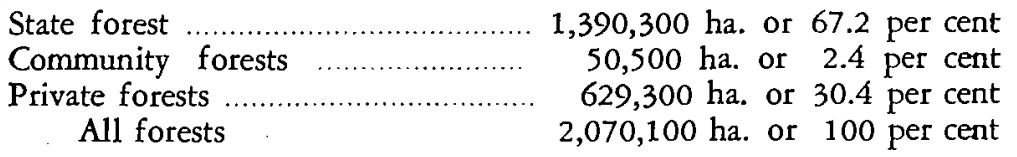

The average annual increment was around 3.0 cubic metres per ha. in the State forests and less than half of this in the private forests. The increment in community forests, the bulk of which was owned by the capital of the country, Riga, was about equal to the increment in the State forests. The average annual increment in all forests of the country including private was about 2.5 cubic metres per hectare. This is not very bad if compared with the average figures given by the U.N. for the average of Europe-2.5.

A special case is the Soviet Union. Pro forma all forests in that country are owned by: the state. Only small parks are owned by some of the towns. Thus, in accordance with this formal conception, there is a total public ownership of forests. But the question arises if there is public ownership as it is understood in the western world. Characteristic features of public ownership in the Western world are: control by the representatives of the people and accounting to these representatives by the specialists in charge. Everybody who knows the regime in the U.S.S.R. has to admit that there are no representatives of the people comparable to those of the western democracies, there is no control by the people and no account to be rendered to the representatives of the people. Therefore, we can hardly speak of a public ownership of forests in that country. I am inclined to compare the forest tenure in U.S.S.R. to the ownership of a large private company where the policy is made by the board of management and the technicians are responsible to this board only. Maybe some people would be inclined to call this kind of ownership a pseudo-public ownership: public ownership in some formal elements, private in accordance with the essence. In that country, in accordance with the data of U.N. for 1949 , the average annual increment is 0.9 cubic metres per hectare.

In accordance with Table No. 6 of the FAO publication, "Forest Resources of the World" (the figures in hectares have been converted into percentages), 27.2 per cent of the forests in U.S.A. are publicly owned and 72.8 per cent are in private ownership. It is clear that the U.S.A. is a country of predominantly private ownership of forests.

The "Forest Resources of the World" (Page 8) states that the average increment for conifers in the U.S.A. is 2.3 cubic metres per hectare. A publication of U.N., "Unasylva", gives the average increment for "North America" (whether this is only for U.S.A. is not indicated) as equal to 1.2 cubic metres per ha. This rate is quite different from that of Germany where the conditions of growth could be called somewhat similar to those of the U.S.A.

Sweden is generally recognized as a country of good forestry. The somewhat low annual increment of 2.1 cubic metres per ha. ("Forest Resources of the World") is due to the fact that a large part of the forests of that country are in the far north. 24.0 per cent of the forests of that country are publicly owned; 76.0 per cent are in private ownership. 
These figures show that Sweden, like the U.S.A. is a land of private forest owners. However, there are several circumstances to be taken into consideration: (1) A large share of the forests under private ownership in Sweden are owned by companies, some of which are very ancient (for instance, "Stora Copparberget" at Fallum) and have developed a remarkable sense of responsibility to the people. (2) Not only the cut but the whole forestry practice is controlled by provincial forestry associations and the foresters of these forestry associations base their policies largely on the results of the work of government research stations. Furthermore, the revenue of these associations to an extent of 43 per cent comes from the government. Thus, the government and the people have a definite influence on the practice of forestry in these privately owned forests.

In these circumstances one should be careful in stating that Sweden is a typical country of unrestricted private ownership of forests. Likewise, there is no evidence that good Swedish forestry practice is entirely due to public influence, although it is true that often the practices in state forests have given a good lead.

The figures for Czechoslovakia quoted below are taken from an old book published in 1926 by the Ministry of Agriculture of the country. (Sylviculture dans la République Tchécoslovaque, Année 1926, No. 66).

The figures for public and private ownership are:

Public Ownership (Collective) 32.0 per cent

Cooperative 9.5 per cent

Private 58.5 per cent

The ownership is very heterogenous in different provinces of the country. It varies from nearly 70 per cent of publicly owned forests, as in Carpatoruthenia, to 79 per cent of privately owned in Bohemia. The average annual increment for the country is 3.4 metres per hectare (op. cit. Page 23). These figures are the highest in forests owned by the church -4.5 cubic metres and in community forests over 500 hectares -4.0 cubic metres. The figures for private forests over $500 \mathrm{ha}$. (where a forester is usually employed) and for state forests are the same: 3.6 cubic metres per hectare. The increment in smaller private forests is considerably lower.

An interesting picture is given by the distribution of age classes in the forests of that country (op. cit. Page 19) -

\begin{tabular}{ccccccc}
\hline Age & $\begin{array}{c}0-20 \\
\text { years }\end{array}$ & $\begin{array}{c}20-40 \\
\text { years }\end{array}$ & $\begin{array}{c}40-60 \\
\text { years }\end{array}$ & $\begin{array}{c}60-80 \\
\text { years }\end{array}$ & $\begin{array}{c}80-100 \\
\text { years }\end{array}$ & $\begin{array}{c}\text { Over 100 } \\
\text { years }\end{array}$ \\
$\begin{array}{c}\text { Percent } \\
\text { of area }\end{array}$ & 22.8 & 22.6 & 19.0 & 17.0 & 11.7 & 6.9 \\
\hline
\end{tabular}

If we look at the percentage of the last two age classes (80-100 and over 100 years) and at the percentage of the first two, we see that the forests of that country have been overcut during the last forty or fifty years.

By looking in the next table in the book we see that in private forests, areas covered by forest over 100 years old are represented by a percentage from 
0.2 to 6.1. However, stands $80-100$ years old in these forests range from 4.5 per cent to 14.3 per cent ( 14.3 per cent only in forests over 500). Figures cited show that different kinds of community forests also are low in the last two age classes, including provincial forests where there are no forests of the two oldest age classes. In the state forests, however, the picture is good: 100 years and over-21.1-24.4 per cent; 80-100 years old-14.1-14.3 per cent.

When studying these figures we cannot help but see that the overcut which appears in the general picture of distribution of age classes has taken place mainly in the private forests. The too high percentage of stands of 100 and more years old in the forests of the state is partly explained by the fact that some of them are in mountains and are hard to get at.

In Czechoslovakia it can be said that the state forests are, from a management angle, on about an equal footing with the big private forests, the latter being worse off regarding the distribution of age classes. But it must be emphasized that some publicly owned forests and especially private forests under 500 ha. (about 1250 acres) alter the result. In addition to the picture given by these statistics, it should be remembered that the forest policies for all forests in that country have been laid down in laws which are the equivalent of state control.

In Switzerland 73.1 per cent of all forests are in public ownership and 26.9 per cent are in private ownership. ("Forest Resources of the World"), Average annual increment is 4.0 cubic metres per ha. Not being in the possession of more detailed data about Switzerland, I can only state from what I have seen there-that foresters could learn much in that country, especially in respect to practices in mountainous regions. It is even of interest to compare Switzerland with France: 63.2 per cent private and 36.8 public forests and 2.6 cubic metres per hectare increment.

In Finland 35.8 per cent of all productive forests are publicly owned63.2 per cent are private. I have seen and learned from talks with Finnish foresters that the state forests there lead in good forestry and it is often quite a problem to persuade private owners to follow suit. The annual increment is indicated as 2 cubic metres per hectare (other sources give 1.2 cubic metres).

After considering all this very limited amount of statistical material which could not be amplified because of lack of literature or because no statistics are available, we see one main tendency, namely, that generally better forestry is practised in forests owned by the state. In some countries big private owners are doing quite well, especially if there is an old tradition of forestry as in some parts of Czechoslovakia where, for instance, a tunnel of more than 1000 feet for floating lumber was constructed through a mountain in 1790 by a private forest owner. (This tunnel is still in use). The general tendency in small private forests seems to be not very encouraging, but as stated at the beginning, these are tendencies rather than laws. It is possible that by analysing more detailed statistical material these tendencies would be more apparent. However, it is doubtful whether it would be possible under any circumstances to transform them into doctrines on the basis of statistical material absolutely applicable always and everywhere.

There are other aspects which should be considered when studying this problem. Firstly, when calculations are made by means of formulae in respect 
to ground rent and forest rent theories, we see that in cases of fairly good forest management the interest on the invested capital usually is somewhere between 1 per cent and 2.5 per cent. The 2.5 per cent figure is usually the maximum. A forest owner has nothing more to do than to pick up his table of compound interest and he would see that, for instance, in fifty years his dollar with 2 per cent compound interest would become $\$ 2.69$, but with 4 per cent it would be $\$ 7.10$. If he ran an eighty year rotation period, the figure would be 4.87 and 23.04 respectively. No doubt an owner who is thinking about forest only on this monetary basis will be influenced by these figures, and it is a fact that many private owners have based their policy solely on such figures. Even foresters who are not used to thinking about forests as a necessary factor in the economical balance of a country are often thinking along these lines. It seems evident that a private owner is bound to be more influenced by interest figures than government which has a feeling of responsibility towards the country and does not act in accordance with the well known slogan of Louis XV-Après nous le déluge.

Secondly, it is true that governments when under financial pressure often adopt a forest policy dictated by the principle of the immediate bighest net. revenue, largely forgetting necessary investments and not bothering about the highest permanent revenue. Sometimes this attitude even goes as far as classification of the forest as a kind of reserve fund which is used to its total exhaustion, or in other words, the forests are mercilessly overcut. But it is observed that this attitude takes place considerably more in private forests (Compare, for instance, the distribution of age classes in private forests in Czechoslovakia and the activities of the government in Great Britain in the establishment of new forests).

Thirdly, usually a private owner is not in a position to evaluate the role of his own forest in the overall picture of the country. Even if he is aware of it, a sound overall conservation policy is very hard to establish. Of course there is the possibility of legislation about forestry practice, about protective and protected forests, etc., but this seems to be more or less a palliative. In this connection, it is interesting to mention a court case. In the State of Washington a Forest Practice Act became effective in January, 1946. This act was not attacked by private owners on the grounds that the practice prescribed by this law is not adequate or not sufficient. Nothing like that. A group of private landowners contested the law on the grounds that it was an infringement of the rights of private property owners. I have not seen this act, but I do not think that it ordered the private owners to destroy their forests. Thus, the main idea of the action of the landowners seems to be to avoid all restriction of their action, even if this action means deterioration of vast areas. The supreme court upheld the legality of the act, (Journal of Forestry, February, 1950).

This case shows two things: One, that the legislative assembly of a state has found it necessary to interfere with the practice of private owners; Two, that at least one group of private owners were not interested in considerations which did not coincide with their private interests as they understood them.

Fourthly, it is an elementary truism that a constant forest policy is necessary if good forestry and good conservation are to be practised. It is utterly 
detrimental to the forests if management plans are changed from year to year without taking into consideration practices required by science. In agriculture, the "rotation period" is one year, but even there it is possible to spoil the soil to such an extent that is is very difficult to repair the damage.

In a democracy there is always the danger that a new minister might throw aside all the work done by his predecessor. Foresters have recognized this possibility and are trying to do their best to stabilize policies. This is why, for instance, the Imperial Forestry Conference, which was held in London in 1947, voiced a strong warning against such behaviour. (See minutes of this conference, Page 242).

But are we entitled to say that the forest policy of private owners is more constant than that of changing governments? In the development of government forest policy there usually is the stabilizing element of the forestry profession, the majority of whom are trying to keep abreast of the achievements of science.

If we want to be impartial, we have to state that after careful consideration of these items we must conclude that it would not be a wise policy just to distribute the total forest amongst private owners. This point of view is strengthened by any study of statistical material.

Now, what about this country? It is true that 87.7 per cent of our forests are in public ownership and only about 12.3 per cent are privately owned. It is true that the increment is low being only 0.8 cubic metres per hectare. But I do not think that this is a direct result of tenure. In Newfoundland there are 72.2 per cent of private forests and only 27.8 per cent of State forests, but the annual increment is 0.5 cubic metres per hectare. It is true that bad forestry has been practised in many places in this country. But would it be a statement which is based on nothing more than the will to find the truth as far as we can find this truth if we say baldly: this state of affairs is due to the fact that 87.7 per cent of our forests are in public ownership? I myself feel compelled to answer with a definite No. An analysis of everything that has been going on in our forests during the last fifty years or so, would indicate that many private forests have been managed to advantage under such ownership, and that much government policy has been undertaken under the mistaken impression that there are "unlimited" forest resources. In many cases the warnings of foresters have been ignored and that has been a grave mistake. The panacea is not a wholesale distribution of forests to Jim and John. This would make matters worse instead of better. 